\title{
Transpiration response of upland rice to water deficit changed by different levels of eucalyptus biochar
}

\author{
Rogério Gomes Pereira(1), Alexandre Bryan Heinemann(2), Beata Emoke Madari(2), \\ Marcia Thais de Melo Carvalho(2), Huberto José Kliemann ${ }^{(1)}$ and Aurélio Pereira dos Santos ${ }^{(2)}$
}

\begin{abstract}
(1)Universidade Federal de Goiás, Faculdade de Agronomia e Tecnologia de Alimentos, Rodovia GO-462, Km 0, Caixa Postal 131, CEP 74690-900 Goiânia, GO, Brazil. E-mail: rogeriogomespereira@hotmail.com, kliemann@agro.ufg.br (2)Embrapa Arroz e Feijão, Rodovia GO-462, Km 12, Zona Rural, CEP 75375-000 Santo Antônio de Goiás, GO, Brazil. E-mail: alexbh@cnpaf.embrapa.br, madari@cnpaf.embrapa.br, marcia@cnpaf.embrapa.br, aureliosantos@cnpaf.embrapa.br
\end{abstract}

\begin{abstract}
The objective of this work was to evaluate the effect of eucalyptus biochar on the transpiration rate of upland rice 'BRSMG Curinga' as an alternative means to decrease the effect of water stress on plant growth and development. Two-pot experiments were carried out using a completely randomized block design, in a split-plot arrangement, with six replicates. Main plots were water stress (WS) and no-water stress (NWS), and the subplots were biochar doses at 0 , 6,12 and $24 \%$ in growing medium (sand). Total transpirable soil water (TTSW), the $\mathrm{p}$ factor - defined as the average fraction of TTSW which can be depleted from the root zone before water stress limits growth -, and the normalized transpiration rate (NTR) were determined. Biochar addition increased TTSW and the p factor, and reduced NTR. Consequently, biochar addition was able to change the moisture threshold ( $p$ factor) of the growing medium, up to $12 \%$ maximum concentration, delaying the point where transpiration declines and affects yield.
\end{abstract}

Index terms: Eucalyptus, Oryza sativa, abiotic stress, water deficit.

\section{Resposta da transpiração de arroz de terras altas ao deficit hídrico modificado por diferentes doses do "biochar" de eucalipto}

\begin{abstract}
Resumo - O objetivo deste trabalho foi avaliar os efeitos do "biochar" de eucalipto na resposta da taxa de transpiração do arroz de terras altas 'BRSMG Curinga', como alternativa para minimizar os efeitos da seca no desenvolvimento e crescimento das plantas. Dois experimentos em vasos foram realizados, em delineamento inteiramente casualizado, em parcelas subdivididas, com seis repetições. As parcelas principais foram constituídas pela deficiência hídrica (WS) e a não deficiência hídrica (NWS), e as subparcelas pelas doses de "biochar" a 0, 6, 12 e 24\% adicionadas ao substrato (areia). A quantidade de água transpirável no solo (TTSW), o fator de depleção (p) - definido como a fração de TTSW que pode ser retirada da zona radicular, antes de a deficiência hídrica limitar o crescimento -, e a taxa de transpiração normalizada (NTR) foram determinados. A adição do "biochar" aumentou a TTSW e o fator p, e reduziu a NTR. Consequentemente, a adição do "biochar" foi capaz de modificar o limiar de umidade (fator p) do substrato, até 12\% de concentração máxima, e retardar o ponto em que a transpiração declina e afeta a produtividade.
\end{abstract}

Termos para indexação: Eucalyptus, Oryza sativa, estresse abiótico, deficiência hídrica.

\section{Introduction}

Upland rice is an alternative to irrigated rice production and is gaining importance in Brazilian savannas (Cerrados) especially because of its lower environmental impact, when it is cultivated in adequate production systems as no-till ones. However, it experiences multiple abiotic stresses which lead to highly variable yields, mainly caused by rainfall variability (Tuong et al., 2000). Production areas are characterized by high heterogeneity related to both climate and soil fertility (Piggin et al., 1998). One of the main environmental limiting factors to rice production is soil water availability, mainly in the
Brazilian savannah, where subsoil acidity leads to restricted rooting depth which increases the effects of moderate droughts. In this region, upland rice producers are mostly small and family-based holdings, who have to manage with low inputs and shallow soil profiles, which exacerbate the effects of water deficits. Biochar, an incompletely combusted organic matter (Glaser et al., 2002; Lehmann et al., 2003), may be a promising alternative to diminish this uncertainty in upland rice production.

Biochar application is an ancient indigenous practice which has recently re-emerged after the study of the anthropogenic dark earth of Amazonia ("terra preta de índio"), which are highly fertile despite being in

Pesq. agropec. bras., Brasília, v.47, n.5, p.716-721, maio 2012 
an environment which stimulates high-leaching and high-soil organic matter decomposition rates (Lehmann et al., 2003). Many studies (Glaser et al., 2002; Lehmann \& Rondon, 2006; Yamato et al., 2006; Brodowski et al., 2007; Atkinson et al., 2010; Lehmann et al., 2011) report that biochar can enhance plant growth by improving soil chemical, physical and biological properties such as available soil moisture, mainly in sandy soils, which leads to higher crop yield. However, there are no studies showing the effect of biochar on the soil moisture threshold ( $\mathrm{p}$ factor), defined as the factor of the fraction of transpirable soil water (FTSW) where transpiration declines and affects yield. The hypothesis is that physiological plant processes, such as transpiration, are influenced by progressive water deficit and that biochar application can delay the inhibition of transpiration in this condition. Transpiration is inhibited when FTSW decreases to values in the range of $40-50 \%$, with a trend which appears to be consistent across a wide range of environments and genotypes (Sadras \& Milroy, 1996).

The objective of this work was to evaluate the effect of eucalyptus biochar on the transpiration rate of upland rice 'BRSMG Curinga' as an alternative means to decrease the effect of water stress on plant growth and development.

\section{Materials and Methods}

Two experiments were conducted at Embrapa Arroz e Feijão, in Santo Antônio de Goiás, GO, Brazil (49 $16^{\circ} 54^{\prime \prime}, 16^{\circ} 29^{\prime} 59^{\prime \prime}$, and $820.4 \mathrm{~m}$ altitude), to evaluate the response of upland rice (Oryza sativa L.) 'BRSMG Curinga' to soil water deficit, at different levels of biochar applied to the growing medium.

'BRSMG Curinga' is described as a medium cycle plant, with 11 to 12 leaves in the main stem (Heinemann et al., 2009). It is considered a modern cultivar and was created in 2005. The experiments were conducted in plastic pots, in greenhouse conditions to minimize systematic bias, in two sowing dates, January $9^{\text {th }}$ and November $4^{\text {th }}, 2009$. The greenhouse climate characterization, during the water stress period, is illustrated in Figure 1 for both sowing dates. It was possible to obtain a range of environmental conditions, in order to minimize the extreme effects of vapor pressure deficit in the transpiration rates, which could affect the normalized transpiration rate (NTR) response to the soil drying process (Sinclair et al., 2008).
The experimental design was a completely randomized in a split plot arrangement, with six replicates. The main plots were water stress (WS) and no-water stress (NWS), and the subplots were biochar doses of 0 (T0), 6 (T1), 12 (T2), and 24\% (T3). Dry sand, previously washed, was used as growing medium. Biochar was ground to pass a $2 \mathrm{~mm}$ sieve and, then, applied and carefully mixed with the dry washed sand. To achieve the correct biochar doses in each treatment, the washed sand was removed to keep constant weight in the pots. The chemical characteristics of the substrates, for each treatment, are described in Table 1. It is worth noting that the total dichromate oxidable soil organic C (SOC), determined by the Walkley-Black method (Claessen, 1997), is one of several key indicators of soil quality (Andrews et al., 2004) and was also modified by biochar addition to the substrate (washed sand). Biochar increased the concentration of SOC fraction, which was measured after upland rice cycle, and was: T0, 0, T1, 36, T2, 58,

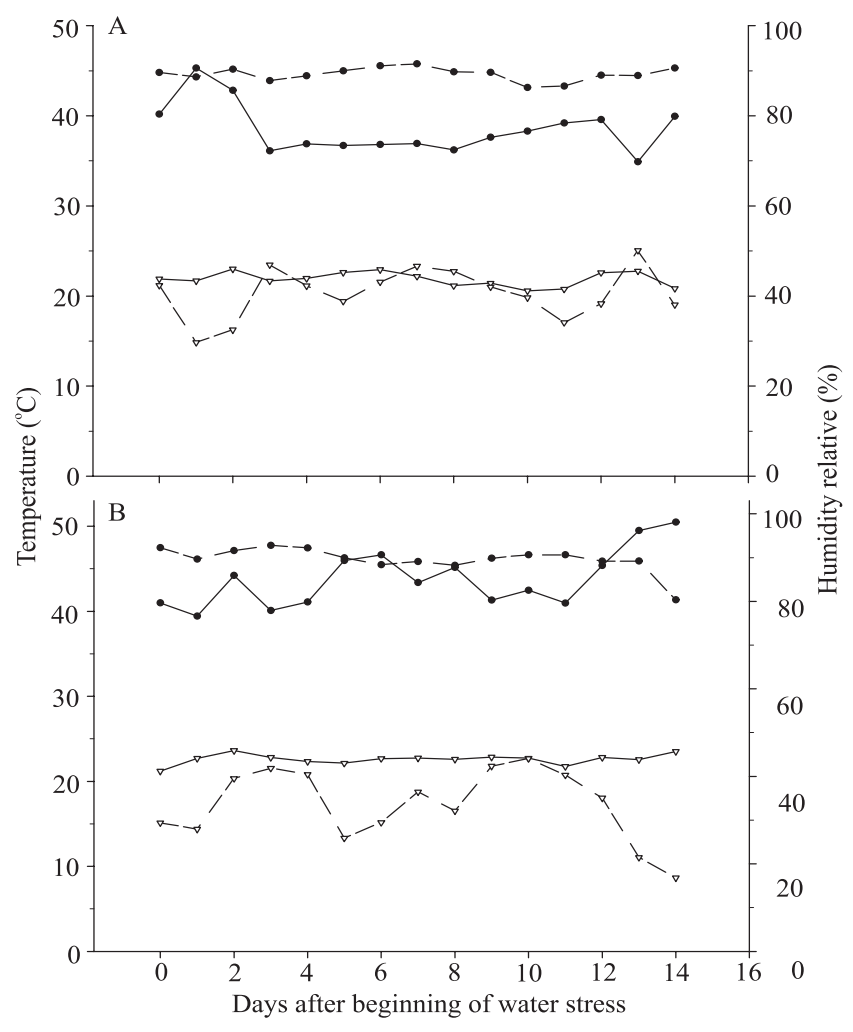

- Maximum temperature _- Maximum relative humidity $\longrightarrow$ Manimum temperature $\quad \rightarrow$ Manimum relative humidity

Figure 1. Daily maximum temperature, minimum temperature, maximum relative humidity and minimum relative humidity in the greenhouse, during the water stress period, for sowing dates in January (A) and November (B), 2009. 
and $\mathrm{T} 3,97 \mathrm{~g} \mathrm{~kg}^{-1}$. Also, $\mathrm{pH}$ values and macro nutrients increased with biochar addition. The biochar used in the experiment is a by-product of the charcoal industry in Brazil, which uses Eucalyptus sp. as raw input material. The elemental composition of the biochar was $774 \mathrm{~g} \mathrm{~kg}^{-1}$ total C, $3 \mathrm{~g} \mathrm{~kg}^{-1}$ total $\mathrm{N}, 57 \mathrm{~g} \mathrm{~kg}^{-1}$ soil organic matter, $3 \mathrm{cmol}_{\mathrm{c}} \mathrm{kg}^{-1} \mathrm{Ca}, 2 \mathrm{cmol}_{\mathrm{c}} \mathrm{kg}^{-1} \mathrm{Mg}, 137 \mathrm{mg} \mathrm{cm}{ }^{-3} \mathrm{P}$, $1,937 \mathrm{mg} \mathrm{cm}^{-3} \mathrm{~K}, 1 \mathrm{mg} \mathrm{cm}{ }^{-3} \mathrm{Cu}, 14 \mathrm{mg} \mathrm{cm}^{-3} \mathrm{Fe}$, $88 \mathrm{mg} \mathrm{cm}^{-3} \mathrm{Mn}$, and $36 \mathrm{mg} \mathrm{cm}^{-3} \mathrm{Zn}$. Total $\mathrm{C}$ and $\mathrm{N}$ were quantified by Dumas method (Nelson \& Sommers, 1996), using the elemental analyzer CNHS/O 2400 Series II PerkinElmer. Extractable elements were quantified according to Claessen (1997).

For each experiment, 48 pots were filled with $7 \mathrm{~kg}$ of substrate, a mixture of dry washed sand and biochar. After germination, plant population was thinned to one plant per pot at the R0 stage (beginning of panicle initiation), according to Counce et al. (2000). Plants were grown under unlimited water and nutrient supply until R0, using a nutritional solution described by Yoshida et al. (1976) and applied at $200 \mathrm{~mL}$ per pot three times a week. According to Heinemann et al. (2008) and Heinemann (2010), at R0 phase, upland rice has the highest probability of suffering water stress in Goiás state. At this development plant stage, soil water evaporation losses were excluded by sealing the pots with plastic film leaving only a small opening for the plant to grow. Half of the pots (24 pots) were kept well watered daily (NWS treatment). The other set of pots were not watered after the R0 stage (WS treatment). All pots were weighted three times a day to estimate transpiration losses.

For the second experiment (sowing date November $4^{\text {th }}, 2009$ ) undisturbed soil samples were taken from each treatment, at the end of the experiment, in order to measure soil water retention curve and bulk density. To compare the soil water retention curves, the observed data for each treatment were adjusted by Van Genuchten's model (Van Genuchten, 1980).
Water content data of the experiment were expressed as a function of the fraction of transpirable soil water (FTSW). The applied methodology was based on Wahbi \& Sinclair (2007) and Heinemann et al. (2011). Total transpirable soil water (TTSW) is the difference between the pot's weight at $100 \%$ of water holding capacity and its weight when transpiration rate of the stressed plants (WS treatment) was less than $10 \%$ of the control plants (NWS treatment). The daily value of FTSW was estimated as the ratio between the amount of water still remaining in the pot and TTSW, as: FTSW $=\left(\mathrm{WT}_{\mathrm{n}}-\mathrm{WT}_{\mathrm{n}+1}\right) / \mathrm{TTSW}$, in which: $\mathrm{WT}_{\mathrm{n}}-\mathrm{WT}_{\mathrm{n}+1}$ is the actual pot weight (amount of transpirable soil water in the pot) in the WS treatment. The actual pot weight was obtained by weighting the pots daily during the drying cycle. The transpiration rate (TR) was calculated by dividing the transpiration of each individual plant, in the WS treatment, by the average transpiration of NWS (control treatment), and it was the first normalization. Then, the TR was re-normalized by dividing each TR value over time by the average of the TR value for the first 2 days of the experiment, before the onset of water limitation in the WS treatment. This second normalization gave the normalized transpiration rate (NTR), which accounted for plant to plant variation in transpiration within each treatment. Transpiration was calculated by subtracting the weight of the covered pots from WS treatments three times a day during the period of water deficit. No attempt was made to correct for the small increase in plant mass during the experiment, which probably resulted in a small error causing a little underestimation in the lower end point (Wahbi \& Sinclair, 2007). The evaluation of the WS treatment ended, when plant transpiration in WS treatment dropped below $10 \%$ of the control treatment (NWS), assuming that in those conditions plants are almost dead.

Values of NTR and FTSW obtained from both experiments (sowing date January $9^{\text {th }}$ and November $4^{\text {th }}$ )

Table 1. Chemical characteristics of the substrates in the treatments T0 ( $0 \%$ biochar), T1 (6\% biochar), T2 (12\% biochar), and T3 (24\% biochar).

\begin{tabular}{|c|c|c|c|c|c|c|c|c|c|c|c|c|}
\hline \multirow[t]{2}{*}{ Treatment } & $\mathrm{pH}$ & $\mathrm{Ca}$ & $\mathrm{Mg}$ & $\mathrm{Al}$ & $\mathrm{H}+\mathrm{Al}$ & $\mathrm{P}$ & $\mathrm{K}$ & $\mathrm{Cu}$ & $\mathrm{Zn}$ & $\mathrm{Fe}$ & $\mathrm{Mn}$ & \multirow{2}{*}{$\begin{array}{l}\mathrm{SOC}^{(1)} \\
\left(\mathrm{g} \mathrm{kg}^{-1}\right)\end{array}$} \\
\hline & water & \multicolumn{4}{|c|}{ - $\left(\mathrm{cmol}_{\mathrm{c}} \mathrm{dm}^{-3}\right)$---- } & $---\cdot$ & -1--- & $-(\mathrm{mg}$ & --- & 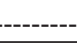 & ------ & \\
\hline T0 & 5.9 & 6.0 & 2.0 & 0.0 & 3.0 & 4.3 & 31.3 & 0.5 & 1.4 & 146.7 & 32.7 & 0 \\
\hline $\mathrm{T} 1$ & 7.6 & 13.7 & 4.0 & 0.0 & 0.0 & 17.8 & 301.3 & 0.2 & 1.4 & 93.3 & 34.7 & 36 \\
\hline $\mathrm{T} 2$ & 7.7 & 16.3 & 5.0 & 0.0 & 0.0 & 26.6 & 499.0 & 0.5 & 1.4 & 83.3 & 35.7 & 58 \\
\hline $\mathrm{T} 3$ & 7.9 & 22.0 & 6.7 & 0.0 & 0.0 & 43.8 & 749.0 & 0.4 & 1.5 & 76.0 & 41.0 & 97 \\
\hline
\end{tabular}

${ }^{(1)}$ Soil organic carbon; C measured by potassium dichromate oxidation, according to Walkley-Black method (Claessen, 1997). 
were all combined to obtain the NTR response curve for each biochar doses as a function of FTSW. The response data were analyzed using a sigmoidal nonlinear model (Heinemann et al., 2011), for comparing the relative transpiration response among upland rice cultivars as: $\mathrm{NTR}=1 /[1+\mathrm{a} \times \exp (-\mathrm{b} \times$ FTSW $)]$, where, $\mathrm{a}$ and $\mathrm{b}$ are empiric parameters obtained by curve fitting.

All regressions were fitted by nls function, from NLME package, R software, v.2.11 (R Development Core Team, 2010).

The $\mathrm{p}$ factor, defined as the average fraction of TTSW which can be depleted from the root zone, before reduction in transpiration occurs, was calculated by the equation $\mathrm{p}=1$ - FTSW, for NTR $=0.95$, in which $\mathrm{p}$ is the depletion factor.

In the present study, the approach used by Sadras \& Milroy (1996) was applied, which considers that $\mathrm{p}$ factor occurs, when NTR equals to 0.95 , as the model plateau is considered to be 1 .

\section{Results and Discussion}

The initial available soil water linearly increased with the increase in biochar doses (Figure 2), for both sowing dates (January 9th and November 4th). This was expected due to the direct impact of biochar on the particle size distribution on the substrate at a macroscale (Brodowski et al., 2007). Therefore, the normalization of the extractable soil water, to calculate the fraction of transpirable soil water (FTSW), did not obscure any major differences in the total amount of water to which the plants had access among treatments. The FTSW values represent roughly equivalent amounts of water removal from the growing medium with the four biochar doses (Wahbi \& Sinclair, 2007). The observed data and empirical model parameters a and $\mathrm{b}$ obtained by the adjusted model are presented in Figure 3. The empirical parameter a in the model is related to the deflection of the curve, and parameter $\mathrm{b}$ to the inclination of the linear model phase. The values obtained for both parameters, $a$ and $b$, differed significantly $(\mathrm{p}<0.05)$ for all treatments. The empirical values obtained in the present study are comparable to those obtained by Heinemann et al. (2011) for upland rice but using an Oxisol as growing medium. The parameter values increased with the increase of biochar doses.

There were differences in the normalized transpiration rate (NTR) for the different biochar doses
(Figure 3). The adjusted model showed that for T0 $(0 \%$ biochar), plant is considered dead when NTR equals to $41 \%$ (Figure $3 \mathrm{~A}$ ). Adding biochar to the growing medium caused a decrease in NTR. Plants died when NTR was equal to 36 (T0), 25 (T1) and 25\% (T3) (Figures 3 B, C and D). These results indicate that biochar increases water holding capacity of sand and, thus, changes the wilting point response of the plant. The $\mathrm{p}$ factor, calculated for treatments $\mathrm{T} 0, \mathrm{~T} 1, \mathrm{~T} 2$ and $\mathrm{T} 3$, was $0.46,0.54,0.66$, and 0.66 respectively. Thus, $\mathrm{p}$ factor increased with biochar doses until T2 (12\%). Besides that, the increase on biochar doses did not have any effect on $p$ value. Therefore, biochar addition can change the moisture threshold ( $\mathrm{p}$ factor) of the growing medium, delaying the point where transpiration declines and affects yield. However, the positive effect of biochar on $\mathrm{p}$ value in the present study is limited to a $12 \%$ dose. The positive biochar effect can be explained by the increase of volumetric water content at higher tensions (Figure 4), in the water retention curve, as well as by the decrease $\left(1.52,1.31,1.17\right.$ and $\left.0.85 \mathrm{~g} \mathrm{~cm}^{-3}\right)$ of the bulk density of the growing medium provoked by biochar addition (0, 6, 12 and 24\%).

Also, many studies on the assessed effect of biochar on crop yield have cited moisture retention as a key

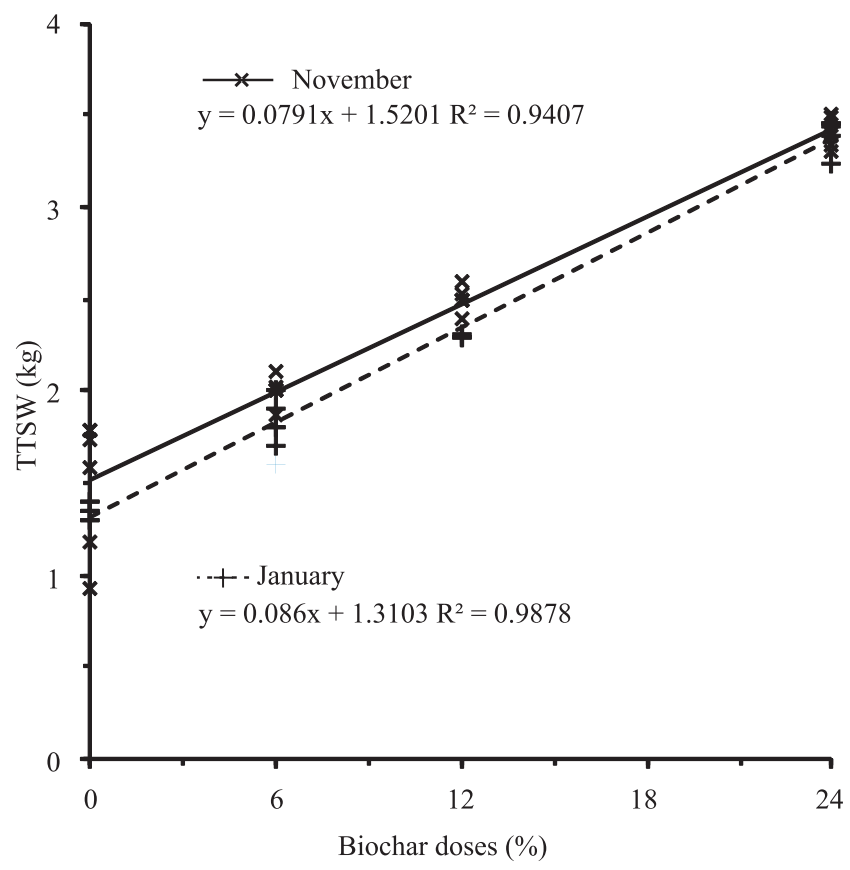

Figure 2. Linear regression of initial total transpirable soil water (TTSW) and different biochar doses (0, 6, 12 and 24\%), for two sowing dates, in January and November, 2009. 
factor in the results (Sohi et al., 2010). Further studies, preferably under field conditions, would be necessary to evaluate the performance of biochar over different soil texture.
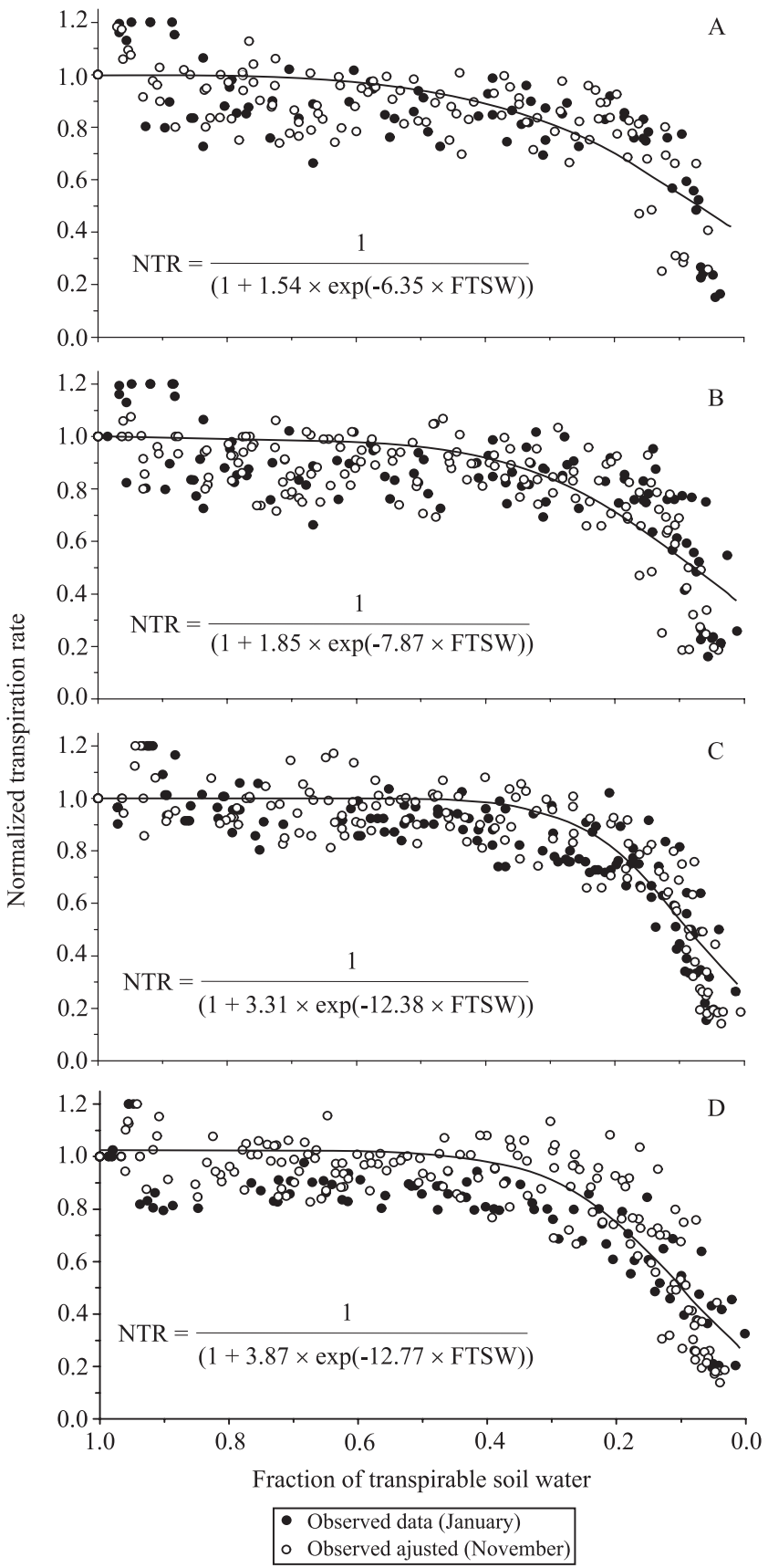

Figure 3. Relationship between the normalized transpiration rate (NTR) and the fraction of transpirable soil water (FTSW), for the upland rice 'BRSMG Curinga' under the application of different doses of biochar - 0\% (A), $6 \%$ (B), $12 \%(C)$, and $24 \%$ (D) - for both sowing dates in January and November, 2009.

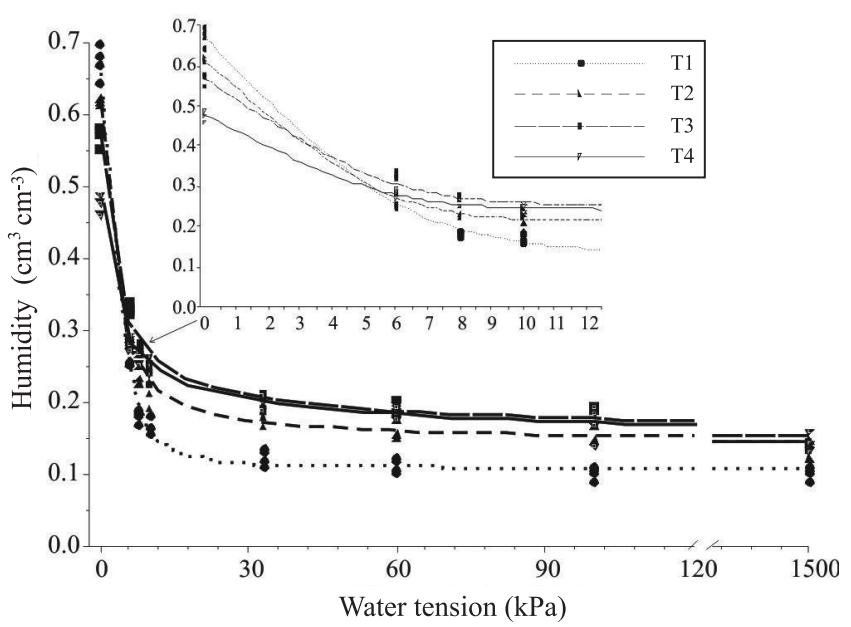

Figure 4. Soil-water retention curve adjusted by van Genuchten's model, obtained for the biochar doses 0 (T1), 6 (T2), 12 (T3) and 24\% (T4) in the growing medium.

\section{Conclusions}

1. Biochar positively affects the amount of soil-water available to upland rice plants.

2. Biochar addition changes the moisture threshold ( $\mathrm{p}$ factor) of the growing medium, delaying the point where transpiration declines.

3. The maximum concentration of biochar with positive effects is $12 \%$, above which biochar has no accumulated effect.

\section{References}

ANDREWS, S.S.; KARLEN, D.L.; CAMBARDELLA, C.A. The soil management assessment framework: a quantitative soil quality evaluation method. Soil Science Society of America Journal, v.68, p.1945-1962, 2004.

ATKINSON, C.J.; FITZGERALD, J.D.; HIPPS, N.A. Potential mechanisms for achieving agricultural benefits from biochar application to temperate soils: a review. Plant and Soil, v.337, p.1-18, 2010.

BRODOWSKI, S.; AMELUNG, W.; HAUMAIER, L.; ZECH, W. Black carbon contribution to stable humus in German arable soils. Geoderma, v.139, p.220-228, 2007.

CLAESSEN, M.E.C. (Org.). Manual de métodos de análise de solo. 2.ed. rev. atual. Rio de Janeiro: Embrapa-CNPS, 1997. 212p. (Embrapa-CNPS. Documentos, 1).

COUNCE, P.A.; KEISLING, T.C.; MITCHEL, A.J. A uniform, objective, and adaptive system for expressing rice development. Crop Science, v.40, p.436-443, 2000.

GLASER, B.; LEHMANN, J.; ZECH, W. Ameliorating physical and chemical properties of highly weathered soils in the tropics 
with charcoal - a review. Biology and Fertility of Soils, v.35, p.219-230, 2002.

HEINEMANN, A.B. Caracterização dos padrões de estresse hídrico para a cultura do arroz (ciclo curto e médio) no estado de Goiás e suas conseqüências para o melhoramento genético. Ciência e Agrotecnologia, v.34, p.29-36, 2010.

HEINEMANN, A.B.; DINGKUHN, M.; LUQUET, D.; COMBRES, J.C.; CHAPMAN, S. Characterization of drought stress environments for upland rice and maize in central Brazil. Euphytica, v.162, p.395-410, 2008.

HEINEMANN, A.B.; STONE, L.F.; FAGERIA, N.K. Transpiration rate response to water deficit during vegetative and reproductive phases of upland rice cultivars. Scientia Agricola, v.68, p.24-30, 2011.

HEINEMANN, A.B.; STONE, L.F.; FAGERIA, N.K.; CASTRO, L.M. de. Evaluation of physiological traits in upland rice for adaptation to no-tillage system. Brazilian Journal of Plant Physiology, v.21, p.113-122, 2009.

LEHMANN, J.; KERN, D.C.; GERMAN, L.A.; MCCANN, J.; MARTINS, G.C.; MOREIRA, A. Soil fertility and production potential. In: LEHMANN, J.; KERN, D.C.; GLASER, B.; WOODS, W.I. (Ed.). Amazonian dark earths: origin, properties, management. Dordrecht: Kluwer, 2003. p.105-124.

LEHMANN, J.; RILLIG, M.C.; THIES, J.; MASIELLO, C.A.; HOCKADAY, W.C.; CROWLEY, D. Biochar effects on soil biota - a review. Soil Biology and Biochemistry, v.43, p.1812-1836, 2011.

LEHMANN, J.; RONDON, M. Bio-char soil management on highly weathered soils in the humid tropics. In: UPHOFF, N.; BALL, A.S.; PALM, C.; FERNANDES, E.; PRETTY, J.; HERRREN, H.; SANCHEZ, P.; HUSSON, O.; SANGINGA, N.; LAING, M.; THIES, J. (Ed.). Biological approaches to sustainable soil systems. Boca Raton: CRC, 2006. p.517-530.

NELSON, D.W.; SOMMERS, L.E. Total carbon, organic carbon and organic matter. In: SPARKS, D.L.; PAGE, A.L.; HELMKE, P.A.; LOEPPERT, R.H.; SOLTANPOUR, P.N.; TABATABAI, M.A.; JOHNSTON, C.T.; SUMNER, M.E. (Ed.). Methods of soil analysis: chemical methods. Madison: Soil Science Society of America: American Society of Agronomy, 1996. p.963-1010. (Soil Science Society of America book series, 5).
PIGGIN, C.; COURTOIS, B.; GEORGE, T.; PANDEY, S.; LAFITTE, R.; KIRK, G.; KONDO, M.; LEUNG, H.; NELSON, R.; OLOFSDOTTER, M.; PROT, J.C.; REVERSAT, G.; RODER, W.; SCHMIT, V.; SINGH, V.P.; TREBUIL, G.; ZEIGLER, R.; FAHRNEY, K.; CASTELLA, J.C. The IRRI upland rice research program: directions and achievements. Los Baños: International Rice Research Institute, 1998. 25p. (IRRI discussion paper series, 25).

R DEVELOPMENT CORE TEAM. R: the R project for statistical computing. Available at: <http://www.r-project.org/>. Accessed on: 24 Nov. 2010.

SADRAS, V.O.; MILROY, S.P. Soil-water thresholds for the responses of leaf expansion and gas exchange: a review. Field Crops Research, v.47, p.253-266, 1996.

SINCLAIR, T.R.; ZWIENIECKI, M.A.; HOLBROOK, N.M. Low leaf hydraulic conductance associated with drought tolerance in soybean. Physiologia Plantarum, v.132, p.446-451, 2008.

SOHI, S.P.; KRULL, E.; LOPEZ-CAPEL, E.; BOL, R. A review of biochar and its use and function in soil. Advances in Agronomy, v.105, p.47-82, 2010.

TUONG, T.P.; KAM, S.P.; WADE, L.; PANDEY, S.; BOUMAN, B.A.M.; HARDY, B. (Ed.). Characterizing and understanding rainfed environments. Los Baños: International Rice Research Institute, 2000. 488p.

VAN GENUCHTEN, M.T. A closed-form equation for predicting the hydraulic conductivity of unsaturated soils. Soil Science Society of America Journal, v.44, p.892-898, 1980.

WAHBI, A.; SINCLAIR, T.R. Transpiration response of Arabidopsis, maize, and soybean to drying of artificial and mineral soil. Environmental and Experimental Botany, v.59, p.188-192, 2007.

YAMATO, M.; OKIMORI, Y.; WIBOWO, I.F.; ANSHIORI, S.; OGAWA, M. Effects of the application of charred bark of Acacia mangium on the yield of maize, cowpea and peanut, and soil chemical properties in South Sumatra, Indonesia. Soil Science and Plant Nutrition, v.52, p.489-495, 2006.

YOSHIDA, S.; FORNO, D.A.; COCK, J.H.; GOMEZ, K.A. Laboratory manual for physiological studies of rice. $3^{\text {rd }}$ ed. Los Baños: International Rice Research Institute, 1976. 83p.

Received on November 25, 2011 and accepted on April 2, 2012 